\title{
ABOUT THE SURGICAL TREATMENT OF DISCOGENIC COMPRESSIONS OF NEURAL ELEMENTS OF THE CERVICAL SPINE
}

\author{
*I.D.Garayev ${ }^{1}$, S.A.Etibarli', E.G.Novruzov ${ }^{1}$, D.D.Mammadov ${ }^{1}$, R.R.Aliyev ${ }^{2}$ \\ ${ }^{1}$ Azerbaijan Medical University, Department of Neurosurgery, Baku, Azerbaijan \\ ${ }^{2}$ Azerbaijan State Advanced Training Institute for Doctors named after A. Aliyev, Department of nervous \\ diseases, Baku, Azerbaijan
}

Keywords: vertebral column, cervical part, spinal disc hernia, discectomy.

According to reference materials, the successful results of surgical treatment of patients, operated for compression of the spinal cord and nerve roots of the cervical cord of spinal canal vary quite widely from 55\% till 96\% [3]. Therefore, the muchdiscussed question of the possible factors that determine the efficiency of surgical intervention in this pathology. Among these factors, the level and prevalence of structural changes of spinal canal, variety of surgical approaches (depending on methods of decompression implementation, carrying out without stabilization or in combination with various kinds of stabilizing operations), features of clinical symptoms and duration till surgery, the presence and severity of associated pathology, the patient's age at the onset of disease and at the time of the operation [1,2].

Some authors suggest that the age of the patient has no effect on the results of surgical treatment, which even in a group of people over 80 years old does not differ from those in younger age groups [5]. In other works, there are examples that with age the frequency of surgical treatment's surgical treatment is reduced and may increase the frequency of post-operative complications [7].

Taking into account that, the age factor in many scientific publications is discussed as significant for the prediction of the post-operative recovery of patients with hernia of the intervertebral disc of cervical zone of vertebral canal, we assumed relevant the estimation of its efficiency in age aspect in the early periods after surgical treatment rate in the age aspect of its efficiency, the dynamics of clinical symptoms and the overall physical state of patients, their satisfaction with the results of the operation. Surgical treatment of the patients with cervical myelopathy with flat lesions currently does not arise any doubts, at the same time the tiered defeat, espe-

* E-mail: ismayil_qarayev@rambler.ru cially on the cover of spondylitis and initially narrow spinal canal often puts surgeon in a difficult situation of selecting tactics of treatment and methods of surgery intervention [8,9].

The determination of intervertebral disc material structures is essential task, as it determines treatment and possible surgical approach. It should be remembered that, not only nerve structures (nerve roots, spinal cord), but also vessels feeding them can be squeezed (radicularmedullary artery, anterior and spinal artery). In this case, nervous frustrations in accordance with the areas of blood supply are added to the segmental radicular manifestations [6].

The indications for surgical treatment of multilevel discogenic compression at the level of the cervical spine, as well as the best ways of surgery intervention rather contradictory, their discussion is ongoing $[1,3]$. As well, the issue of creating spinal fusion and the need of additional fixation of the vertebral column using various metal structures is discussed question. The urgency of the surgical treatment problem of such patients is due great dissemination of this disease, severe neurological dysbarism and post-surgical complications, and that determined the purpose of scientific study.

The purpose of the study was the identification of surgical treatment system of patients with degenerative diseases of the cervical spine for maximum improvement of treatment results basing on modern and minimally invasive surgical procedures.

Anterior discectomy and stabilization of the cervical spine. A similar method was first proposed by Leroy and Abbort at the University of Michigan (USA), and the first surgical operation was carried out by surgeons Bailey and Badgley of the same university in 1952. Since main method of surgical treatment for hernias of the intervertebral discs of the cervical spine become 
the anterior cervical discectomy with interbody spondylosyndesis. In this case the intervertebral disc is removed through interbody gap, the partial of whole carving of vertebral body is carried out. For spine fusion auto transplant is traditionally been applied from the iliac crest.

In the 60-s anterior approach for treatment of degenerative lesions of the cervical spine was widely disseminated thanks to works of R.B.Cloward, G.W.Smith and R.A.Robinson. Bohler, the metal plate with screws for additional fixation of the cervical spine from anterior approach was first used in 1964; the results were published in Germany three years later. In 1970 Orozco and LlovetTapies first reported the usage of AO/ASIF plates with screws. In the early 80's Caspar started using their own plates with screws [7,8]. Since 1985, nearly all used plates were either Caspar/Aesculap system (Aesculap, South San Francisco, CA) or Orozco/AO/ASIF/Synthesis system (Synthesis Spine, Paoli, PA). The peculiarity of these plates was that the screws were not fixated in the plate and for solid fixation they had to be conducted through two cortical layer of the vertebra that increase the risk of damage to the spinal cord and nerve roots. Furthermore, these plates were made of steel, and after their installation it is not possible to carry out the MR-tomography.

First titanium front plate with locking screws in plates developed Morsher in 1986. In this case, the screws with locking were fixed on the plate, and in their turn increased the stabilization. This made the construction more robust and secure. As it was not necessary to conduct these plates through two cortical vertebral layers, they were called monocortical, unlike the previous ones - bicortical.

The new generation of plates is made from titanium and is MRI-compatible. There were plates with polyaxial screws, in other words, with the possibility of installation screws at various angles to plate, simultaneously with fixation of screws to the plate itself that eliminate all inconveniences and disadvantages of previous generation plates.

Different modifications of cages began to be applied in practice in 90's for facilitating the interbody stabilization of the cervical spine. Installation of cages instead of remote disc give opportunity for immediate segmental stability, correction of deformation in sagittal plane, recovering the ability of the frontal vertebral column to resist loads [4,9]. Different constructions have their own advantages and disadvantages. By this way the cages from double carbon fibre brushes are roentgenolucent, that facilitate the assessment of bone changes, but they can have inflammatory response, they are fragile. Titanium mesh constructions easily fastened between bodies, as they have sharp spikes on the ends. They are filled with bone chips, which contribute to bone spine fusion. However, the main complication of installing such cages is their deflexion with time under axial loads in bodies of adjacent vertebrae [8]. Therefore the development of cages was and currently is according to the principle of strengthening the biocompatibility and maximizing the support of surface that is well integrated with the bone tissue of adjacent vertebrae. In most structures there is a cavity for autologous bone or for other materials to accelerate the formation of bone block between vertebrae. The most important advantages of modern cages are following: easy installation after ventral decompression and removing of intervertebral discs; the possibility of selecting necessary cage under recovered intervertebral gap relying on existence of several cage measures; the possibility of maintenance sagittal deformation of vertebra after removing of distraction influence of tools; less probability of cage migration according to the usage of special surface materials ( titanium nickelide, tantalum), spikes (Solis), terrain and thrust pads (Sofamor Danek), etc.

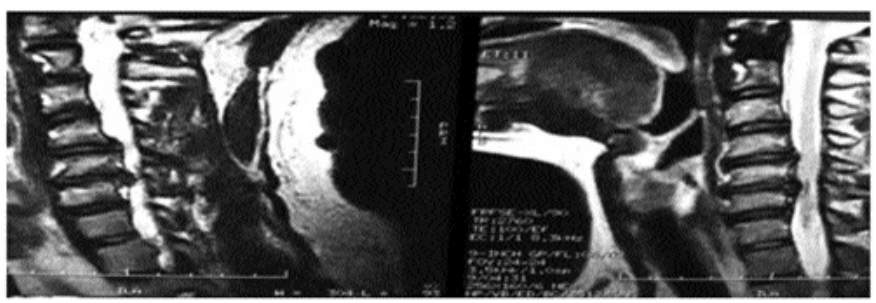

Fig.1. Cervical MRT, disc hernia in C4-C5, C5-C6



Fig. 2. Axial, disc hernia in C4-C5. 


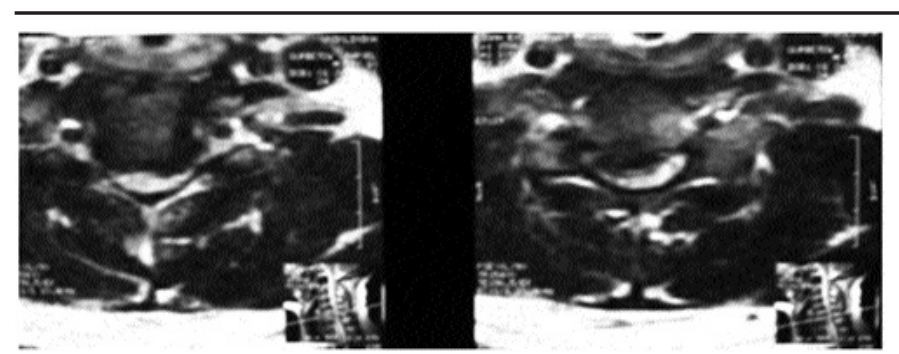

Fig. 3. Axial, disc hernia at the level of C5-C6, spinal stenosis

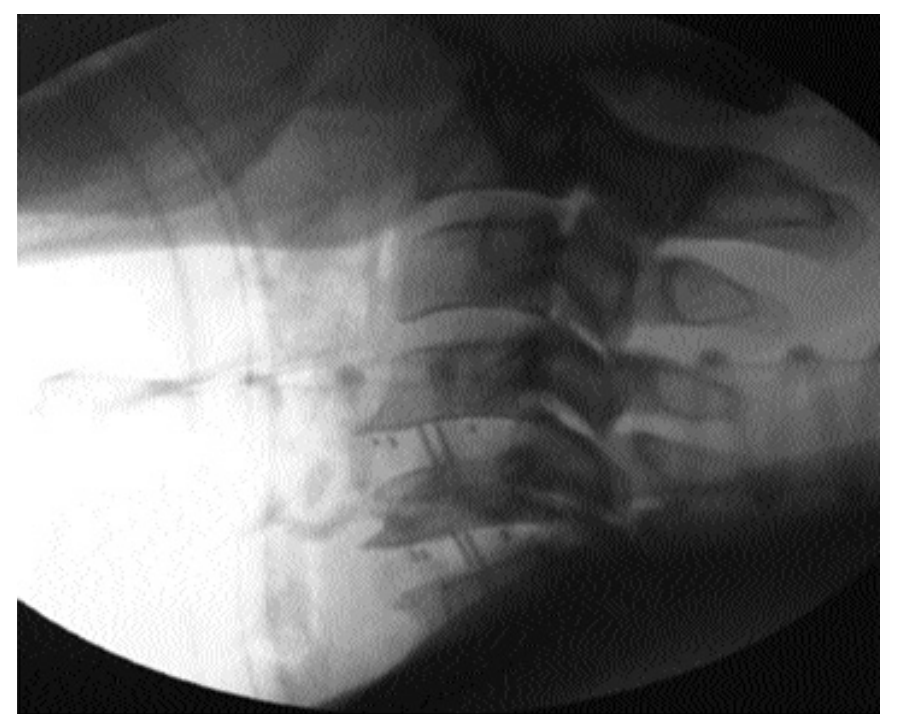

Fig. 4. The view of cage installed in C4-C5, C5-C6 disc intervals in postop $\mathrm{R}$ examination.

Material and methods of research. We have analysed the results of surgical treatment of 44 patients with cervical intervertebral disc hernia, operated in Republican Neurosurgical hospital, Central hospital of seamen and at the "Uniclinic" medical centre within the period of 2009-2014. The average age of the patients was $43.5(60-27)$ years. Men were more than women 1.4:1. The

\section{REFERENCES}

1. Педаченко Ю. Є. Клініко-морфологічні особливості стенозу вальних процесів поперекового відділу хребтового каналу у хворих різних вікових груп // Ю. С. Педаченко, О. П. Красиленко. - Вісник Сумського державного університету. Серія Медицина. 2011. - №2. - с. 66 - 76

2. Педаченко Е.Г., Танасейчук А.Ф., Хижняк М.В., Педаченко Ю.Е.: Эндоскопическая микрохирургия при грыжах шейных дисков // Вопросы нейрохирургии, 2003, № 1, с. 7-14.

3. Черепанов А.Е. Новости зарубежной вертебрологии // Хирургия позвоночника. 2004.- №1. С.128-130.

4. Хелимский А.М. Нейрохирургическое лечение хронических дискогенных болевых синдромов шейного и поясничного остеохондроза. Дисс. докт. мед. наук.Хабаровск.- 1996.- 378 с.

5. Design of the Spine Patient outcomes Research Trial neurological status for the presence of motor and sensory deficits, symptoms of nerve root or spinal cord compression, dysfunction of the pelvic organs were assessed in all patients. The pain syndrome before treatment was observed in all patients with discogenic compression. Patients were conducted spondylography with functional tests, CT and MRI of the cervical spine.

Results of surgical treatment. All patients underwent surgical treatment, including discectomy (7), laminectomy (2), corporectomy and frontal fusion (1), discectomy and auto transplantation (7), discectomy and cage installation (27). For enhancing the stabilization of cages, we have used titanium plates, that reduce time required for external immobilization of cervical spine after surgery. The results of applying anterior approach with interbody stabilization considered excellent in patients with disk syndrome, but in the presence of discogenic myelopathy - if the present illness of conducting disorders did not exceed 3 months. The surgical treatment has resulted in achieving stabilization of the spine and regression of neurological status, including absence of pain, increase in volume and force of active movements in limbs, recovery of pelvic organs' recovery, and improvement of sensitivity.

Conclusion. The surgical treatment of discogenic compression of neural elements of cervical spine using minimum invasive methods of access and modern implants increases the number of excellent and good results of operations and give opportunity for avoiding unsatisfactory results.

(SPORT) / Birkmeyer N. J., Weinstein J. N., Tosteson A. N. et al. // Spine. - 2002. - Vol. 27. - P. 1361-1372

6. Deyo R.A., Ciol M.A., Cherkin D.C. et al. Cervical spinal fusion. A cohort study of complications, reoperations, and resource use in the Medicare population // Spine. 1993. -Vol. 18. - P. 1463- 1470

7. Zdeblick T.A., Phillips F.M. Interbody cage devices // Spine. 2003.- Aug.- 1;28(15 Suppl):S2-7.

8. Stoll T.M., Dubois G., Schwarzenbach O. The dynamic neutralization system for the spine: a multi-center study of a novel non-fusion system // Eur. Spine J.- 2002. Oct.-11 Suppl.- 2:S 170-8.- Epub.- 2002.- Sep. 10.

9. Stieber J.R., Brown K., Donald G.D., et al. Anterior cervical decompression and fusion with plate fixation as an outpatient procedure. Clinical Studies // Spine J. 2005.Vol. 5.- N. 5.- P. 503-507. 


\title{
XÜLASə
}

\section{ONURĞANIN BOYUN NAHIYYYOSI SINIIR ELEMENTLORININ DISSKOGEN KOMPRESSIYASININ CORRAHİ MÜALICCOSİ HAQQINDA}

\author{
İ.C.Qarayev ${ }^{1}$, S.A.Etibarlı ${ }^{1}$, E.H.Novruzov ${ }^{1}$, C.C.Məmmədov ${ }^{1}$, R.R.Oliyev ${ }^{2}$ \\ ${ }^{1}$ Azarbaycan Tibb Universiteti, Neyrocarrahiyy kafedrasl, Bakl, Azarbaycan; \\ ${ }^{2}$ O. Oliyev ad. Azərbaycan Dövlat Həkimlari Təkmilləşdirmə Institutu, sinir xəstaliklari kafedrası, \\ Bakl, Azarbaycan
}

\begin{abstract}
Odəbiyyata əsasən fəqərə sütunu boyun nahiyyəsində onurğa beyni və sinir kökcüklərinin kompressiyası səbəbi ilə əməliyyat olunmuş xəstələrdə əməliyyatın müsbət nəticələri 55-96\% arasında dəyişir. Cərrahiyyə əməliyyatından sonrakı başlanğıc müddətdə, əməliyyatın yaş aspektlərinə əsasən effektivliyini, klinik simptomlarının dinamikasını, xəstələrin ümumi fiziki vəziyyətini, onların əməliyyat nəticələri üzrə məmnunluqlarını qiymətləndirməyi aktual hesab etdik.

Biz onurğanın boyun nahiyyəsinin fəqərəarası disk yırtığısəbəbiylə cərrahi əməliyyat olunmuş 44 xəstə üzərində, əməliyyatın nəticələri üzrə analiz aparmışıq. Xəstələrə diskektomiya (7), laminektomiya (2), korporektomiya və ön korporodez (1), diskektomiya və autoplastika (7), keyc yerləşdirilməklə diskektomiya (27) cərrahi müalicə üsulları tətbiq edilmişdir. Aparılan cərrahi müalicə üsulu ağrının aradan qaldırılması, ətrafların həcminin və aktiv fəaliyyətinin, həmçinin çanaq orqanlarının funksiyalarının bərpası, həssaslığın artırılması da daxil olmaqla onurğanın sabitləşdirilməsi və nevroloji statusun reqresiyası şəklində müşahidə olundu.
\end{abstract} Açar sözlər: onurğa sütunu, boyun şöbəsi, disk yırtığı, diskektomiya.

\section{PЕЗЮМЕ}

\section{О ХИРУРГИЧЕСКОМ ЛЕЧЕНИИ ДИСКОГЕННЫХ КОМПРЕССИЙ НЕРВНЫХ ЭЛЕМЕНТОВ ШЕЙНОГО ОТДЕЛА ПОЗВОНОЧНИКА}

\author{
И.Д. Гараев ${ }^{1}$, С.А. Этибарлы ${ }^{1}$, Э.Г. Новрузов ${ }^{1}$, Д.Д. Маммедов ${ }^{1}$, Р.Р.Алиев ${ }^{2}$ \\ 'Азербайджанский Медицинский Университет, Кафедра Нейрохирургии, Баку, Азербайджан; \\ ${ }^{2}$ Азербайджанский Государственный Институт Усовершенствования Врачей им. А. Алиева, \\ Баку, Азербайджан
}

По литературным данным, успешные результаты хирургического лечения больных, оперированных по поводу компрессии спинного мозга и корешков шейного отдела позвоночного столба варьируют в достаточно широких пределах - от 55\% до 96\%. Нам представлялось актуальным в ранние сроки после хирургического лечения оценить в возрастном аспекте его эффективность, динамику клинической симптоматики и общего физического состояния пациентов, их удовлетворённость результатами операции. Нами проведен анализ результатов хирургического лечения 44 больных страдающих грыжей межпозвонкового диска шейного отдела. Больным проведено хирургическое лечение, включающее дискэктомию (7), ламинэктомию (2), корпорэктомию и передний корпородез (1), дискэктомию и аутопластику (7), дискэктомию и наложение кейджа (27). Проведенное хирургическое лечение привело к достижению стабилизации позвоночника и регресса неврологического статуса, включая отсутствие боли, увеличение объёма и силы активных движений в конечностях, восстановление функций тазовых органов, улучшение чувствительности.

Ключевые слова: позвоночный столб, шейный отдел, грыжа межпозвоночный диска, дискэктомия

Redaksiyaya daxil olub: 03.11.2014

Çapa tövsiyə olunub: 01.12.2014

Rayçi: t.e.d., prof. R.K.Şiraliyeva 